\title{
Article \\ Optimum Sowing Window and Yield Forecasting for Maize in Northern and Western Bangladesh Using CERES Maize Model
}

\author{
Apurba Kanti Choudhury ${ }^{1}\left(\right.$, Md. Samim Hossain Molla ${ }^{2}$, Taslima Zahan ${ }^{3}{ }^{\circledR}$, Ranjit Sen ${ }^{4}$, \\ Jatish Chandra Biswas ${ }^{5}$, Sohela Akhter ${ }^{4}$, Sheikh Ishtiaque ${ }^{3}$, Faruque Ahmed ${ }^{6}$, Md. Maniruzaman ${ }^{7}$, \\ Md. Belal Hossain ${ }^{7}$, Parimal Chandra Sarker ${ }^{1}$, Eldessoky S. Dessoky ${ }^{8}\left(\mathbb{D}\right.$, Mohamed M. Hassan ${ }^{8}(\mathbb{D})$ \\ and Akbar Hossain $9, *(\mathbb{B}$
}

check for updates

Citation: Choudhury, A.K.; Molla, M.S.H.; Zahan, T.; Sen, R.; Biswas,

J.C.; Akhter, S.; Ishtiaque, S.; Ahmed, F.; Maniruzaman, M.; Hossain, M.B.; et al. Optimum Sowing Window and Yield Forecasting for Maize in Northern and Western Bangladesh Using CERES Maize Model. Agronomy 2021, 11, 635. https:// doi.org/10.3390/agronomy11040635

Academic Editor: Jiftah Ben-Asher

Received: 22 February 2021

Accepted: 24 March 2021

Published: 26 March 2021

Publisher's Note: MDPI stays neutral with regard to jurisdictional claims in published maps and institutional affiliations.

Copyright: (c) 2021 by the authors. Licensee MDPI, Basel, Switzerland. This article is an open access article distributed under the terms and conditions of the Creative Commons Attribution (CC BY) license (https:// creativecommons.org/licenses/by/ $4.0 /)$.
1 Seed Technology Division, Bangladesh Agricultural Research Institute (BARI), Gazipur 1701, Bangladesh; apurba.chowdhury@gmail.com (A.K.C.); sarkerparimalch@yahoo.com (P.C.S.)

2 On-Farm Research Division (OFRD), BARI, Rangpur 5400, Bangladesh; samimmolla@yahoo.com

3 OFRD, BARI, Gazipur 1701, Bangladesh; taslimazahan_tzp@yahoo.com (T.Z.); ishtiaque@bari.gov.bd (S.I.)

4 Soil Science Division, BARI, Gazipur 1701, Bangladesh; senranjitbd@yahoo.com (R.S.); sohela_akhter@yahoo.com (S.A.)

5 Soil Science Division, Bangladesh Rice Research Institute (BRRI), Gazipur 1701, Bangladesh; jatishb@yahoo.com

6 Plant Physiology Division, BARI, Gazipur 1701, Bangladesh; faruquebari@gmail.com

7 Irrigation and Water Management Division, BRRI, Gazipur 1701, Bangladesh; mzamaniwm@yahoo.com (M.M.); belal.iwm@gmail.com (M.B.H.)

8 Department of Biology, College of Science, Taif University, P.O. Box 11099, Taif 21944, Saudi Arabia; es.dessouky@tu.edu.sa (E.S.D.); m.khyate@tu.edu.sa (M.M.H.)

9 Bangladesh Wheat and Maize Research Institute, Dinajpur 5200, Bangladesh

* Correspondence: akbarhossainwrc@gmail.com

Abstract: Determination of the optimum sowing window not only can improve maize yield significantly but also can fit maize in the existing cropping pattern. To get the advantages of sowing maize at the optimum time, a study was designed and carried out at the research field of Bangladesh Agricultural Research Institute, Rangpur, Bangladesh during 2015-2017. Another aim of the study was to forecast the yield of maize for the northern and western regions of Bangladesh using the CERES-Maize model. The study considered 5 November, 20 November, 5 December, 20 December, and 5 January as sowing dates for maize to identify the optimum sowing window. Three hybrid maize varieties, viz., BARI Hybrid Maize-9 (BHM-9), NK-40, and Pioneer30V92 were used. The study was laid out in a split-plot design, assigning the sowing dates in the main plot and the varieties in the sub-plot. To forecast the yield, the daily weather data of 2017 were subjected to run the model along with thirty years (1986-2015) of weather data. The genetic coefficients of the tested maize varieties were obtained through calibration of the model by using the observed field data of 2015-2016 and through validation by using the data of 2016-2017. The seasonal analysis was done using the DSSAT CERES-Maize model to confirm the experimental findings for optimizing the sowing window for maize at the northern region (Rangpur) of the country and subsequently adjusted the model for the western region (Jashore). The model performances were satisfactory for crop phenology, biomass, and grain yield. The NRMSE for anthesis was $0.66 \%$ to $1.39 \%, 0.67 \%$ to $0.89 \%$ for maturity date, $1.78 \%$ to $3.89 \%$ for grain yield, and $1.73 \%$ to $3.17 \%$ for biomass yield. The optimum sowing window for maize at the Rangpur region was 5 November to 5 December and 5 to 20 November for the Jashore region. The CERES-Maize model was promising for yield forecasting of the tested maize varieties. It gave a realistic yield forecast at approximately 45 days prior to the harvest of all the tested varieties. The study results are expected to be useful for both the farmers and the policy planners to meet up the future maize demands.

Keywords: climate change; crop model; grain yield; maize; sowing window; yield forecast 


\section{Introduction}

The area of maize (Zea mays L.) is remarkably increasing in Bangladesh [1] as it has a great demand in the poultry industry [2]. Over the last 10 years (2010-2020), the production of maize has substantially increased from 1954 to 4400 thousand tons [3]. The northern and western parts of Bangladesh are the important regions for maize production [2-4]. The major hindrance of growing maize in these regions is to fit the crop within the existing rice-based cropping pattern. In those areas, the transplanted rainy season rice (aman rice) is commonly grown in all the existing patterns, which is rice occupied in field upto the end of October; and therefore, no lands can get free for growing maize early than November. Moreover, after the harvest of rainy season rice, the lands remain moist due to the late monsoon. Therefore, it is very crucial to optimize sowing time for maize to fit in a pattern.

Maize has the benefit to grow both in winter and pre-monsoon seasons because of its facultative nature to day-length [5]. Tropical maize varieties are photo-period sensitive, and thus, long days in high latitudes allow maize plants to grow tall but with less grain yield. Moreover, air temperature sometimes can directly influence the grain growth of maize [6]. Several studies have confirmed that maize yield significantly decreases with falling temperature [7]. Usually, plants require a definite growing degree day (GDD) to get maturity, depending on daily temperature and date of sowing.

The sowing date has a great influence on both growth and yield of crops because of environmental variations over time and space. For example, late sowing of sunflower experiences lower temperature, with a decrease in GDD from 1731 to 1621 during the grain filling period [8] resulting in low yield. However, the response of maize varieties to sowing dates can be dissimilar depending on adopted management practices. Soler et al. [9] reported a 55\% yield loss in four hybrid maize varieties because of delay in sowing under rainfed condition, whereas the loss was only $21 \%$ in irrigated condition. Therefore, the knowledge on the sowing window of a variety at any particular location is important to attain maximum yield [10].

To ensure the attainable yield under the changing climatic scenario and also to avoid the costly time-consuming long-term experiments to address the long-term climatic variability issues, a reliable well-accepted strategic validated crop model can be helpful [11-13]. Among the crop models, APSIM (Agricultural Production Systems Simulator) and DSSAT (Decision Support System for Agro-technology Transfer) are the most widely and frequently used models [14]. Tovihoudji [14] and several other researchers notified that the DSSAT CERES-Maize module implemented in DSSAT [15] for simulating maize growth and yield is suitable for a broad range of soil, management, and climatic conditions in comparison to APSIM [16-19]. Many researchers have already used the DSSAT model to get good crop management practices to minimize production risks [20-25]. Soler et al. [26] used this model to forecast maize yield. Therefore, the present study was designed and executed with an aim to identify the best sowing date for hybrid maize varieties in the northern region of Bangladesh and to forecast the yield before harvest. Another aim of the study was to adjust the sowing window for maize in the western region of the country based on the results of the northern region.

\section{Materials and Methods}

\subsection{Field Experiments}

An experiment was conducted with three hybrid maize varieties, viz., BARI Hybrid Maize-9 (BHM-9), NK-40, and Pioneer30V92 at the research field of On-Farm Research Division, Bangladesh Agricultural Research Institute (BARI), Rangpur $\left(25^{\circ} 43^{\prime} 28.9^{\prime \prime} \mathrm{N}\right.$ and $89^{\circ} 15^{\prime} 80.7^{\prime \prime}$ E, elevation $8 \mathrm{~m}$ ) during 2015 to 2017 . Five dates were considered for maize varieties, viz., 5 November, 20 November, 5 December, 20 December, and 5 January, to get the optimum sowing window. The experimental design was split-plot, arranging the sowing date in main plots and the varieties in the sub-plots. The number of replication was three and the unit plot size was $6 \mathrm{~m} \times 4 \mathrm{~m}$. Maize seeds were sown at $20 \mathrm{~kg} \mathrm{ha}^{-1}$ maintaining $60 \mathrm{~cm} \times 20 \mathrm{~cm}$ plant spacing. The experimental field was fertilized with $\mathrm{N}, \mathrm{P}, \mathrm{K}$, and $\mathrm{S}$ 
@ 250, 55, 100, and $30 \mathrm{~kg} \mathrm{ha}^{-1}$, respectively. The sources of N, P, K, and S were urea, triple superphosphate, muriate of potash and gypsum, respectively. One-third of $\mathrm{N}$ and the entire amounts of other plant nutrients were applied one day prior to sowing. The remaining two-thirds $\mathrm{N}$ was applied at 35 and 65 days after sowing as a top dressing. Supplementary irrigation was added at knee height and cob initiation stage. Manual weeding was done as and when necessary to keep the crop-weed competition at a minimum level. No control measure was required for pest or disease.

\subsection{Weather and Soil Information}

Daily air temperatures (maximum and minimum), rainfall, and sunshine hours were collected from the nearby weather station of the experimental field under the Bangladesh Meteorological Department, Rangpur. Solar radiation was derived from sunshine hour using Weather Man software in the CERES-Maize model (Figure 1). The averages of the two years' cumulative total rainfall were around 413, 601, 650, 667, and $773 \mathrm{~mm}$ for the 1st, 2nd, 3rd, 4th, and 5th sowing dates, respectively. Similarly, maize plants received $1828,1901,1809,1847$, and $1822 \mathrm{MJ} \mathrm{m}^{-2} \mathrm{~d}^{-1}$ solar radiations for five different sowing dates, respectively. Maximum temperatures $\left({ }^{\circ} \mathrm{C}\right)$ were $27.2,27.4,27.4,28.1$, and 28.6, respectively, for first to 5th seeding. Similarly, minimum temperatures $\left({ }^{\circ} \mathrm{C}\right)$ were $15.5,15.2,15.4,16.1$, and 16.9, respectively. Total rainfall during the crop growing period of 2015-2016 was much higher than that of 2016-2017, therefore, irrigation frequency and quantity were more in the second year (Table 1).

\subsection{Model Description}

DSSAT CERES-Maize model is used to simulate crop growth and development on a daily basis under a wide range of environments [27]. This model effectively considers all the parameters in the simulation that directly or indirectly influence the grain yield of maize. The model also assesses the commencement of phenological events.

Cultivar specific parameters (CSPs) are developed by the generalized likelihood uncertainty estimation (GLUE) program of DSSAT v4.6. To perform such task scientifically, the model requires date of emergence, anthesis, physiological maturity duration, grain yield, biomass yield, grains in cob, and individual grain weight, thermal time interval from seedling emergence to end of the juvenile stage (P1), coefficient of photoperiod sensitivity (P2), degree days requirement for physiological maturity considering the base temperature of $8{ }^{\circ} \mathrm{C}(\mathrm{P} 5)$, maximum possible kernel number in a plant (G2), grain filling rate in $\mathrm{mg}$ day $^{-1}$ (G3), and phyllocron interval (PHINT) in days. Initially, a large number (6000) of parameter values are generated by GLUE and then likelihood values are calculated for each set of coefficients using differences between observed and simulated data [28].

\subsection{Model Calibration and Validation}

The CERES-Maize model was calibrated according to Hunt and Boote [29] by utilizing the data of grain yield, aboveground biomass yield, anthesis period, physiological maturity, number and weight of kernel that were collected from the first-year trial (2015-2016). These data were copied in an existing DSSAT maize file and run in the model with the observed weather and soil file. The process was repeated and error was adjusted until the best match was found for the observed and simulated growth duration and grain yield. The derived genotypic coefficients were used for validation of the model based on the observed data of 2016-2017 and then the model performance was evaluated for application. 

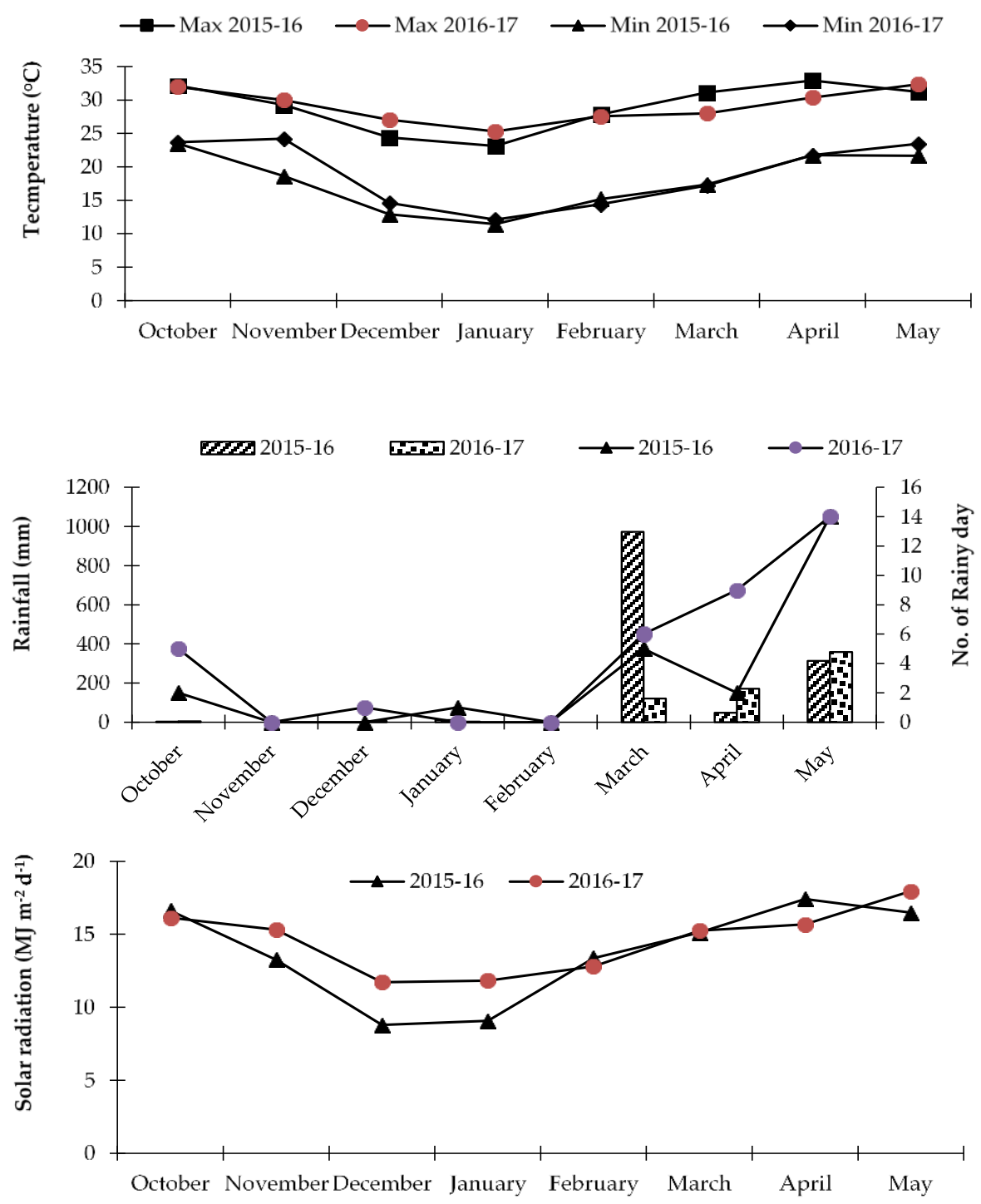

Figure 1. Monthly average of temperature, rainfall, and solar radiation for the two consecutive growing seasons of maize (2015-2016 and 2016-2017) at Rangpur, Bangladesh.

Table 1. Historical weather data of Rangpur and Jashore during the growing season of maize (average of 30 years).

\begin{tabular}{|c|c|c|c|c|c|c|c|c|}
\hline \multirow{3}{*}{ Month } & \multicolumn{4}{|c|}{ Average Temperature $\left({ }^{\circ} \mathrm{C}\right)$} & \multirow{2}{*}{\multicolumn{2}{|c|}{ Total Rainfall (mm) }} & \multirow{2}{*}{\multicolumn{2}{|c|}{ Average Sunshine (h) }} \\
\hline & \multicolumn{2}{|c|}{ Maximum } & \multicolumn{2}{|c|}{ Minimum } & & & & \\
\hline & Rangpur & Jashore & Rangpur & Jashore & Rangpur & Jashore & Rangpur & Jashore \\
\hline October & 30.7 & 32.5 & 22.5 & 22.9 & 169.1 & 124.0 & 7.2 & 6.2 \\
\hline November & 28.5 & 30.3 & 17.3 & 17.4 & 7.8 & 28.2 & 7.8 & 6.8 \\
\hline December & 24.8 & 26.7 & 13.0 & 12.5 & 7.9 & 11.1 & 6.7 & 6.1 \\
\hline January & 23.0 & 25.4 & 10.9 & 11.1 & 9.1 & 13.4 & 6.1 & 6.3 \\
\hline February & 26.4 & 29.0 & 13.4 & 14.7 & 11.7 & 25.4 & 7.5 & 7.2 \\
\hline March & 30.5 & 33.6 & 17.5 & 19.7 & 27.6 & 42.3 & 7.8 & 7.4 \\
\hline April & 31.7 & 35.9 & 21.3 & 23.6 & 117.9 & 72.6 & 7.1 & 7.6 \\
\hline May & 31.9 & 35.5 & 23.4 & 25.2 & 284.7 & 180.3 & 6.5 & 6.9 \\
\hline
\end{tabular}

For soil properties, initially, soil samples were collected from four depths (0-15, 15-30, $30-60$, and 60-90 cm). Collected samples were subjected to analysis to determine the physical properties such as texture, bulk density, moisture content, and field capacity; and the chemical properties such as $\mathrm{pH}$, organic matter, and total $\mathrm{N}$ (Tables 2 and 3 ). 
Table 2. The soil texture of the initial soil in the experimental field.

\begin{tabular}{cccc}
\hline Soil Depth $\mathbf{( c m )}$ & Sand (\%) & Silt (\%) & Clay (\%) \\
\hline $0-15$ & 11 & 63 & 26 \\
$15-30$ & 11 & 60 & 29 \\
$30-60$ & 14 & 33 & 53 \\
$60-90$ & 27 & 38 & 35 \\
\hline
\end{tabular}

Table 3. Physicochemical properties of the initial experimental soil.

\begin{tabular}{cccccc}
\hline $\begin{array}{c}\text { Soil Depth } \\
\text { (cm) }\end{array}$ & $\mathbf{p H}$ & $\begin{array}{c}\text { Bulk } \\
\text { Density (g } \\
\mathbf{c m}^{-3} \text { ) }\end{array}$ & $\begin{array}{c}\text { Organic } \\
\text { Carbon (\%) }\end{array}$ & TotalN (\%) & $\begin{array}{c}\text { Field } \\
\text { Capacity (\%) }\end{array}$ \\
\hline $0-15$ & 5.4 & 1.37 & 1.60 & 0.10 & 39.54 \\
$15-30$ & 6.5 & 1.42 & 0.61 & 0.08 & 39.37 \\
$30-60$ & 6.4 & 1.37 & 0.45 & 0.05 & 40.79 \\
$60-90$ & 6.5 & 1.44 & 0.21 & 0.03 & 38.29 \\
\hline
\end{tabular}

\subsection{Evaluation of CERES-Maize Model}

The model was evaluated using the index of agreement (d) [30], root mean square error (RMSE) and normalized RMSE [31], mean absolute percentage error (MAPE) [32], and percentage of predicted deviation (PD), as shown in Equations (1)-(5). Variables such as the emergence of maize, anthesis and maturity, aboveground biomass, and grain yields were evaluated in the study.

$$
\mathrm{PD}=\frac{O_{i}-S_{i}}{O_{i}}
$$

Here, $O_{i}$ and $S_{i}$ refers to observed and simulated variables.

$$
d=1-\left\lfloor\frac{\sum\left(P_{i}-O_{i}\right)^{2}}{\sum\left(\left|P_{i}\right|+\left|O_{i}\right|\right)^{2}}\right\rfloor
$$

Here, $P_{i}$ and $O_{i}$ refers to predicted and observed data.

$$
\text { RMSE }=\sqrt{\frac{1}{n} \sum_{1}^{n}\left(X_{s}-X_{o}\right)^{2}}
$$

MAPE was determined as follows:

$$
\mathrm{MAPE}=\frac{1}{n} \sum_{1}^{n} \frac{X_{s}-X_{o}}{X_{s}} \times 100 \%
$$

Here, $n$ indicates the number of comparisons, $X_{S}$ is the simulated yield, and $X_{o}$ is the observed yield. NRMSE was determined as follows:

$$
\text { NRMSE }=\frac{\text { RMSE }}{X} \times 100 \%
$$

Here, " $x$ " is the average observed yield.

$\mathrm{PD}$ value tending to zero indicates perfect prediction. Negative divergence indicates under prediction, but positive deviation means over prediction. A closer d-stat value to unity indicates good simulation. The RMSE is widely used to find out statistical differences between predicted and observed data [33]. If NRMSE is $<10$ and $>10$ but $<20$, then the prediction is considered as excellent and good, respectively. 


\subsection{Seasonal Analysis and Model Application}

The validated CERES-Maize model was utilized to predict grain yields through seasonal analysis considering the same weather and soil data, and coefficients of tested genotypes under multiple runs for one season and five sowing times. Thirty years of weather data obtained from the Bangladesh Meteorological Weather Station at Rangpur and Jashore were used for running the model.

\subsection{Yield Forecasting}

Yield forecasting for three hybrid maize was accomplished through the use of the CERES-Maize model. Daily weather data for 30 years from Bangladesh Meteorological Weather Station, Rangpur were normalized and combined with daily recorded weather data for 2017. Bi-weekly yield forecasting were made, starting from mid-January until the end of May 2017. For these forecast results, the antecedent daily weather data of 2017 were used until the forecast date, complemented with 30 years of normalized weather data for the remaining growing season. For each forecast, the mean and standard deviations for the forecasted yield were determined.

\section{Results and Discussion}

\subsection{Genetic Coefficient Determination}

The adjustment of CSPs is needed for model calibration so that observed data match well with simulated values [34]. The "P" values (P1, P2, and P5) of CSPs were computed by observed dates of anthesis and physiological maturity. These values were used to find out the dates of the phenological events such as anthesis and physiological maturity for field application. The values of G2 and G3 control the yield contributing characters such as grain dry matter yield, straw yield (aboveground biomass), grain size, etc. Detailed descriptions of the genetic coefficient values are shown in Table 4. The computed CSPs values for BHM-9, NK-40, and Pioneer30V92 were put into the cultivar (CUL) file (MZCER046.CUL) to calibrate and validate the model.

Table 4. CERES-Maize genetic coefficient for BHM-9, NK-40, and Pioneer30V92 varieties.

\begin{tabular}{ccccccc}
\hline \multirow{2}{*}{ Variety } & \multicolumn{7}{c}{ Cultivar Specific Parameters (CSPs) } \\
\cline { 2 - 7 } & P1 & P2 & P5 & G2 & G3 & PHINT \\
\hline BHM-9 & 308.1 & 0.300 & 950.6 & 785.1 & 8.40 & 47.00 \\
NK-40 & 310.0 & 0.300 & 948.0 & 782.0 & 8.50 & 47.00 \\
Pioneer30V92 & 306.0 & 0.300 & 940.0 & 776.0 & 8.50 & 47.00 \\
\hline
\end{tabular}

\subsection{Model Calibration Results}

The simulated grain and biomass yields, anthesis, and physiological maturity of all the tested maize varieties during 2015-2016 were similar with observed data. However, observed data were slightly lower than the simulated values (Figure 2). The calibration results under five dates of sowings at Rangpur location for grain yields were $R^{2}=0.96$, RMSE $=128$, NRMSE $=1.26$, and $d=0.94$, for biomass $R^{2}=0.93$, RMSE $=298$, NRMSE $=1.40$, and $\mathrm{d}=0.91$, for anthesis date $\mathrm{R}^{2}=0.98, \mathrm{RMSE}=0.42$, NRMSE $=0.43$, and $\mathrm{d}=0.96$, and for physiological maturity were $\mathrm{R}^{2}=0.99$, RMSE $=58$, NRMSE $=0.42$, and $\mathrm{d}=0.96$ (Figure 2). Therefore, model calibrations for grain and biomass yields, anthesis date, and physiological maturity were analogous to the observed values with $R^{2}$ approaching one. These differences were rather small and also supported the good statistical indices. 


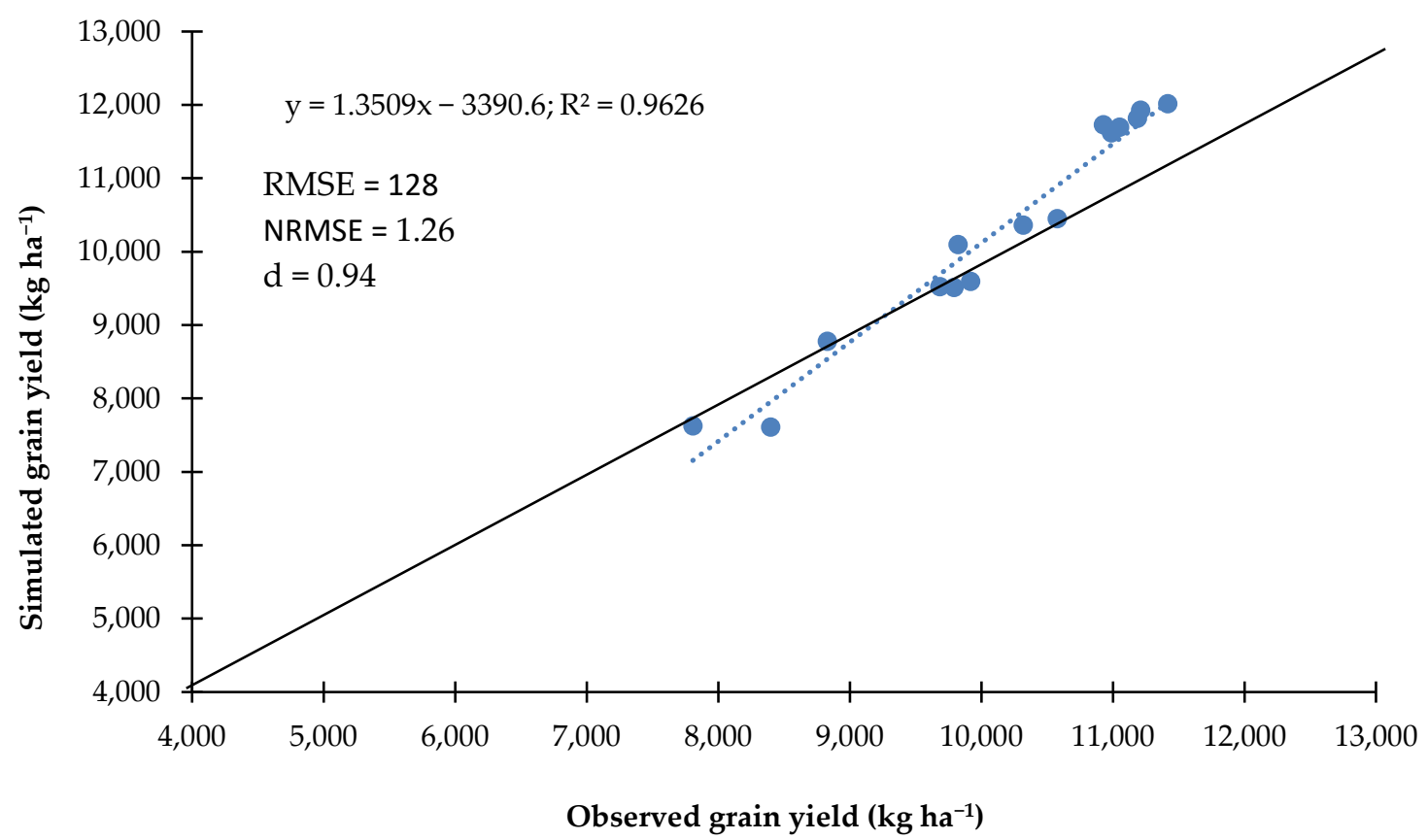

Figure 2. Calibration results of grain yield with their goodness of fit during the year 2015-2016.

\subsection{Model Validation}

The simulated grain and biomass yields, anthesis, and physiological maturity dates of all the tested maize varieties under five sowing dates were similar to the observed data. The test statistics for validation results were $0.93<\mathrm{R}^{2}<0.97 ; 175<\mathrm{RMSE}<401 ; 1.78<$ NRMSE $<3.89$; and $0.98<\mathrm{d}<0.99$ for grain yields; $0.91<\mathrm{R}^{2}<0.97 ; 373<\mathrm{RMSE}<658$; $1.73<$ NRMSE $<$ 3.17; and $0.86<\mathrm{d}<0.96$ for biomass yields; $0.82<\mathrm{R}^{2}<0.95$; $0.63<\mathrm{RMSE}<1.34 ; 0.66<$ NRMSE $<1.39$; and $0.91<\mathrm{d}<0.94$ for anthesis date, and $0.99<\mathrm{R}^{2}<1.00 ; 0.94<\mathrm{RMSE}<1.13$; $0.67<$ NRMSE $<0.82$; and $0.96<\mathrm{d}<0.97$ for physiological maturity (Table 5). Therefore, model validation for grain and biomass yields, anthesis day, and physiological maturity were well fitted to the observed values with $\mathrm{R}^{2}$ approaching to one. However, the CERESMaize model was well parameterized, showing a good performance in simulating phenology, growth, and yield of maize varieties. In previous studies, this model was also provided with comparable results [35,36].

\subsection{Phenological Development Phases and Yields}

The observed and simulated outputs were compared after the calibration of the model. The percent deviation (\%PD) of the simulated data from the observed values were calculated. The model predicted anthesis and physiological maturity periods for five sowing dates, which have been presented in Table 6. Irrespective of varieties, the differences between observed and simulated anthesis and physiological maturity were +1 to +3 and +1 to +3 days, respectively. Close prediction of anthesis and maturity days with 0 - to 2-days difference between observed and simulated values were also noticed by Soler et al. [26]. Chisanga et al. [27] found the CERES-Maize model predicted days to anthesis $(-2$ to \pm 1$)$ and maturity ( -4 to \pm 1 ) within the range of observed data. Deviations of phenological stages from the observed values were 0 to $-3.13 \%$ at anthesis and from $-0.8 \%$ to $-2.2 \%$ at physiological maturity. 
Table 5. Indicators of the goodness of fit for grain and biomass yields, and growth duration using CERES-Maize model validation irrespective of sowings dates at Rangpur, Bangladesh during 2016-2017.

\begin{tabular}{|c|c|c|c|c|c|}
\hline Parameters & $\mathbf{R}^{2}$ & RMSE & MAPE & NRMSE & $\mathrm{D}$ \\
\hline & & \multicolumn{4}{|c|}{ ВHМ-9 } \\
\hline Yield, $\mathrm{kg} \mathrm{ha}^{-1}$ & 0.93 & 192 & 13.93 & 1.92 & 0.98 \\
\hline Tops weight, $\mathrm{kg} \mathrm{ha}^{-1}$ & 0.97 & 373 & 7.81 & 1.73 & 0.96 \\
\hline * ADAP, days & 0.82 & 1.34 & 2.54 & 1.39 & 0.93 \\
\hline \multirow[t]{2}{*}{${ }^{*} \mathrm{MDAP}$, days } & 1 & 0.94 & 3.59 & 0.67 & 0.96 \\
\hline & & \multicolumn{4}{|c|}{ NK-40 } \\
\hline Yield, $\mathrm{kg} \mathrm{ha}^{-1}$ & 0.97 & 401 & 13.21 & 3.89 & 0.98 \\
\hline Tops weight, $\mathrm{kg} \mathrm{ha}^{-1}$ & 0.91 & 476 & 7.21 & 2.21 & 0.92 \\
\hline ADAP, days & 0.95 & 0.63 & 2.76 & 0.66 & 0.94 \\
\hline \multirow[t]{2}{*}{ MDAP, days } & 1 & 0.94 & 3.73 & 0.67 & 0.96 \\
\hline & & \multicolumn{4}{|c|}{ Pioneer30V92 } \\
\hline Yield, $\mathrm{kg} \mathrm{ha}^{-1}$ & 0.91 & 175 & 14.01 & 1.78 & 0.99 \\
\hline Tops weight, $\mathrm{kg} \mathrm{ha}^{-1}$ & 0.97 & 658 & 7.95 & 3.17 & 0.86 \\
\hline ADAP, days & 0.93 & 0.85 & 3.00 & 0.89 & 0.91 \\
\hline MDAP, days & 0.99 & 1.13 & 3.77 & 0.82 & 0.97 \\
\hline
\end{tabular}

${ }^{*} \mathrm{ADAP}=$ anthesis days after planting, and $\mathrm{MDAP}=$ maturity days after planting.

Table 6. Comparison between observed and simulated, and percent differences for phenological development stages, grain, and biomass yields as affected by different sowing dates and maize hybrids with the CERES-Maize model at Rangpur, Bangladesh during 2016-2017.

\begin{tabular}{|c|c|c|c|c|c|c|c|c|c|}
\hline \multirow{2}{*}{$\begin{array}{c}\text { Phenological } \\
\text { Stages }\end{array}$} & Obs. & Sim. & $\%$ PD & Obs. & Sim. & $\%$ PD & Obs. & Sim. & $\%$ PD \\
\hline & \multicolumn{3}{|c|}{ BHM-9 } & \multicolumn{3}{|c|}{ NK-40 } & \multicolumn{3}{|c|}{ Pioneer30V92 } \\
\hline & \multicolumn{9}{|c|}{5 November } \\
\hline Anthesis day & 99 & 98 & 1.01 & 98 & 98 & 0.00 & 98 & 98 & 0.00 \\
\hline Maturity day & 145 & 148 & -2.1 & 145 & 148 & -2.1 & 145 & 148 & -2.1 \\
\hline Grain $\left(\mathrm{kg} \mathrm{ha}^{-1}\right)$ & 10,062 & 10,047 & 0.1 & 10,020 & 10,150 & -1.3 & 10,285 & 10,065 & 2.1 \\
\hline \multirow[t]{2}{*}{ Biomass $\left(\mathrm{kg} \mathrm{ha}^{-1}\right)$} & 22,319 & 23,231 & -4.1 & 23,457 & 23,464 & 0.0 & 22,633 & 23,310 & -3.0 \\
\hline & \multicolumn{9}{|c|}{20 November } \\
\hline Anthesis day & 99 & 99 & 0.0 & 98 & 99 & -1.02 & 96 & 99 & -3.13 \\
\hline Maturity day & 144 & 146 & -1.4 & 144 & 146 & -1.4 & 143 & 145 & -1.4 \\
\hline Grain $\left(\mathrm{kg} \mathrm{ha}^{-1}\right)$ & 11,650 & 10,833 & 7.0 & 11,474 & 10,925 & 4.8 & 11,042 & 10,626 & 3.8 \\
\hline \multirow[t]{2}{*}{ Biomass $\left(\mathrm{kg} \mathrm{ha}^{-1}\right)$} & 22,306 & 23,207 & -4.0 & 17,440 & 18,617 & -6.7 & 22,075 & 23,328 & -5.7 \\
\hline & \multicolumn{9}{|c|}{5 December } \\
\hline Anthesis day & 96 & 98 & -2.1 & 96 & 98 & -2.1 & 96 & 98 & -2.1 \\
\hline Maturity day & 140 & 142 & -1.4 & 140 & 142 & -1.4 & 139 & 142 & -2.2 \\
\hline Grain $\left(\mathrm{kg} \mathrm{ha}^{-1}\right)$ & 11,150 & 11,220 & -0.6 & 11,481 & 11,315 & 1.4 & 10,998 & 11,240 & -2.2 \\
\hline \multirow[t]{2}{*}{ Biomass $\left(\mathrm{kg} \mathrm{ha}^{-1}\right)$} & 22,763 & 23,557 & -3.5 & 21,701 & 23,405 & -7.9 & 23,115 & 23,287 & -0.7 \\
\hline & \multicolumn{9}{|c|}{20 December } \\
\hline Anthesis day & 95 & 97 & -2.1 & 95 & 97 & -2.1 & 95 & 97 & -2.1 \\
\hline Maturity day & 136 & 138 & -1.5 & 136 & 138 & -1.5 & 135 & 138 & -2.2 \\
\hline Grain $\left(\mathrm{kg} \mathrm{ha}^{-1}\right)$ & 10,051 & 10,542 & -4.9 & 10,847 & 10,631 & 2.0 & 9904 & 10,561 & -6.6 \\
\hline \multirow[t]{2}{*}{ Biomass $\left(\mathrm{kg} \mathrm{ha}^{-1}\right)$} & 17,942 & 18,677 & -4.1 & 21,935 & 23,246 & -6.0 & 21,745 & 23,257 & -7.0 \\
\hline & \multicolumn{9}{|c|}{5 January } \\
\hline Anthesis day & 93 & 93 & 0.0 & 92 & 93 & -1.1 & 91 & 92 & -1.10 \\
\hline Maturity day & 131 & 132 & -0.8 & 130 & 131 & -0.8 & 129 & 130 & -0.8 \\
\hline Grain $\left(\mathrm{kg} \mathrm{ha}^{-1}\right)$ & 7005 & 6937 & 1.0 & 7005 & 6937 & 1.0 & 6971 & 6730 & 3.5 \\
\hline Biomass $\left(\mathrm{kg} \mathrm{ha}^{-1}\right)$ & 21,420 & 23,330 & -8.9 & 21,619 & 23,215 & -7.4 & 17,100 & 17,888 & -4.6 \\
\hline
\end{tabular}


However, up to November seeding, observed anthesis and maturity days were 99 and 145, respectively. Anthesis and maturity days reduced under late sowing dates. On 5 January sowing, anthesis and maturity days were 91 to 92 and 129 to 131, respectively. Due to late planting from November to January, days to anthesis of maize decreased. The possible reason could be prevailing high temperatures during the pre-flowering stage in late-planted maize, decreased GDD, and thus leading to early maturity of the crop. Ahmed et al. [31] also reported a similar incidence in late-planted maize. The increment of both maximum and minimum temperature shortens the duration of flowering and maturity of maize [33]. In the present study, the deviation in simulated grain and biomass yields from the observed values ranged from $-2.2 \%$ to $+1 \%$ and $-8.9 \%$ to $0 \%$, respectively. The second and third sowing dates ( 20 November and 5 December) produced higher grain yields satisfactorily which was close to the yield of 5 November sowing. Grain yield reduced beyond 5 December sowing, and the lowest was obtained from 5 January planting. Liaqat et al. [37] also marked a reduction in grain yield for delayed planting. Biswas [38] reported similar findings and identified 20 to 30 November as the optimum sowing time for hybrid maize at Jamalpur district of Bangladesh.

\subsection{Seasonal Outputs}

Long-term simulated grain yield of maize varied from 10,039 to $11,839 \mathrm{~kg} \mathrm{ha}^{-1}$ in Rangpur. Varietal performances were almost similar for five sowing dates. The highest grain yield of maize was attained when sown on 5 November, and the lowest on 5 January seeding, which was similar to the 4th and 5th sowing dates (Figure 3a). Gradual decrement of grain yield was from November to early January sowing. Biomass yield also followed a similar trend. Prolonged life duration and favorable temperature, especially at the grain filling stage, might be the main reason for the higher grain yield of maize in early sowing dates. Ahmed et al. [31] also reported similar findings in maize. The relationship between grain yield and different sowing dates of maize are linear. Simulated grain yield was higher in November sowing and decreased thereafter. The lowest grain yield was obtained in January sowing. Considering varietal performances, NK-40 and Pioneer30V92 gave higher grain yields in all the sowing dates compared to BHM-9, though the differences were not remarkable. On average, about $300 \mathrm{~kg} \mathrm{ha}^{-1}$ grain yields reduced for every 15 days' delay in sowing date. On the other hand, the long-term simulated grain yield of maize in the Jashore region ranged from 6512 to $10,034 \mathrm{~kg} \mathrm{ha}^{-1}$. Varietal performances were almost similar in five sowing dates (Figure $3 b$ ). Sowing dates follow a sharp linear relationship; the simulated yield on 5 November was higher and close to 20 November sowing, and then declined gradually with late sowing dates. With a delay in the sowing date from 5 November to 20 November, yield reductions were $872-891 \mathrm{~kg} \mathrm{ha}^{-1}$. This indicates that a farmer may delay sowing because of the unsuitability of land or other socioeconomic conditions, but he/she has to lose about one-ton grain yield than the optimum seeding time. Our findings are concurrent with that of Porter and Semenov [39] and Adnan et al. [16] that early planting offered benefit to achieve targeted maize yield while the risk of yield reduction increased with the delay in planting.

\subsection{Yield Forecasting}

High variability with yield forecasting was observed during February and March sowing, as seen from the large standard deviations (Figure 4). The standard deviation of simulated grain yield decreased for all three hybrids with the progress of a growing season when the simulations were run, considering an extensive period with real weather data of 2017 (Figure 4). For all the tested varieties, the standard deviation of the estimated yields for 1st April was close to zero (Figure $4 \mathrm{a}-\mathrm{c}$ ), but at the end of the growing season, the simulated and observed yields in 2016-2017 were similar (triangle points in Figure 4). These similarities were expected because the CERES-Maize model was evaluated using observed grain yields. Using observed weather data of 2017, we found perfect yield prediction at least 45 days prior to harvest for all three maize varieties. Similar findings have been 
reported by others for millets [40], groundnut [41], and maize [6]. The tested CERES-Maize model showed many potentialities for yield predictions. The present study confirms the findings of Boggione et al. [42] and Amaral et al. [43], who forecasted maize yield through CERES-Maize and got satisfactory results. However, the study suggests calibrating and validating the model before application for new hybrids in the new location under different agro-climatic conditions.
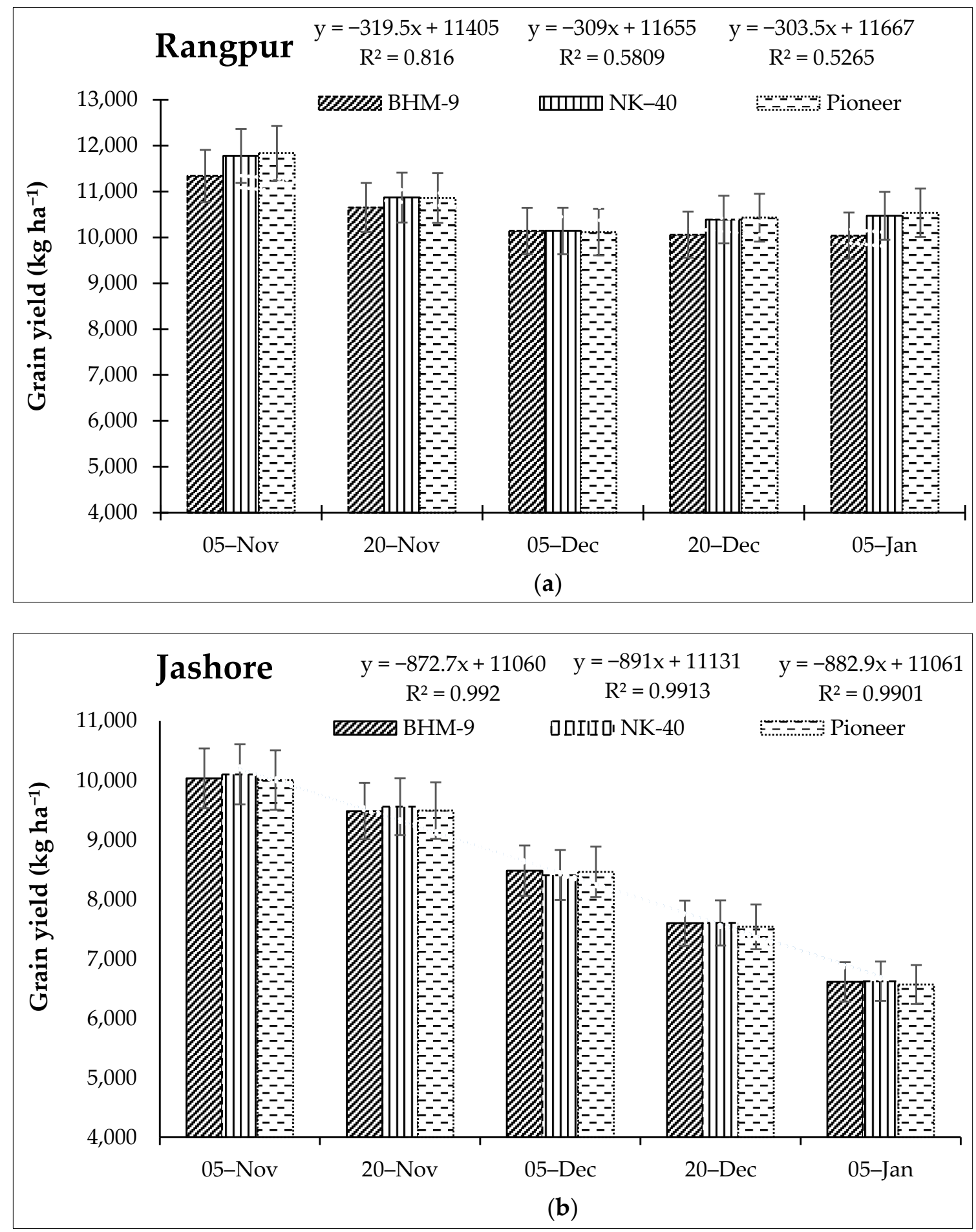

Figure 3. (a) Grain yield of maize as affected by sowing dates at Rangpur region considering 30 years of historical data. (b) Grain yield of maize as affected by sowing dates at Jashore region considering 30 years of historical data. 

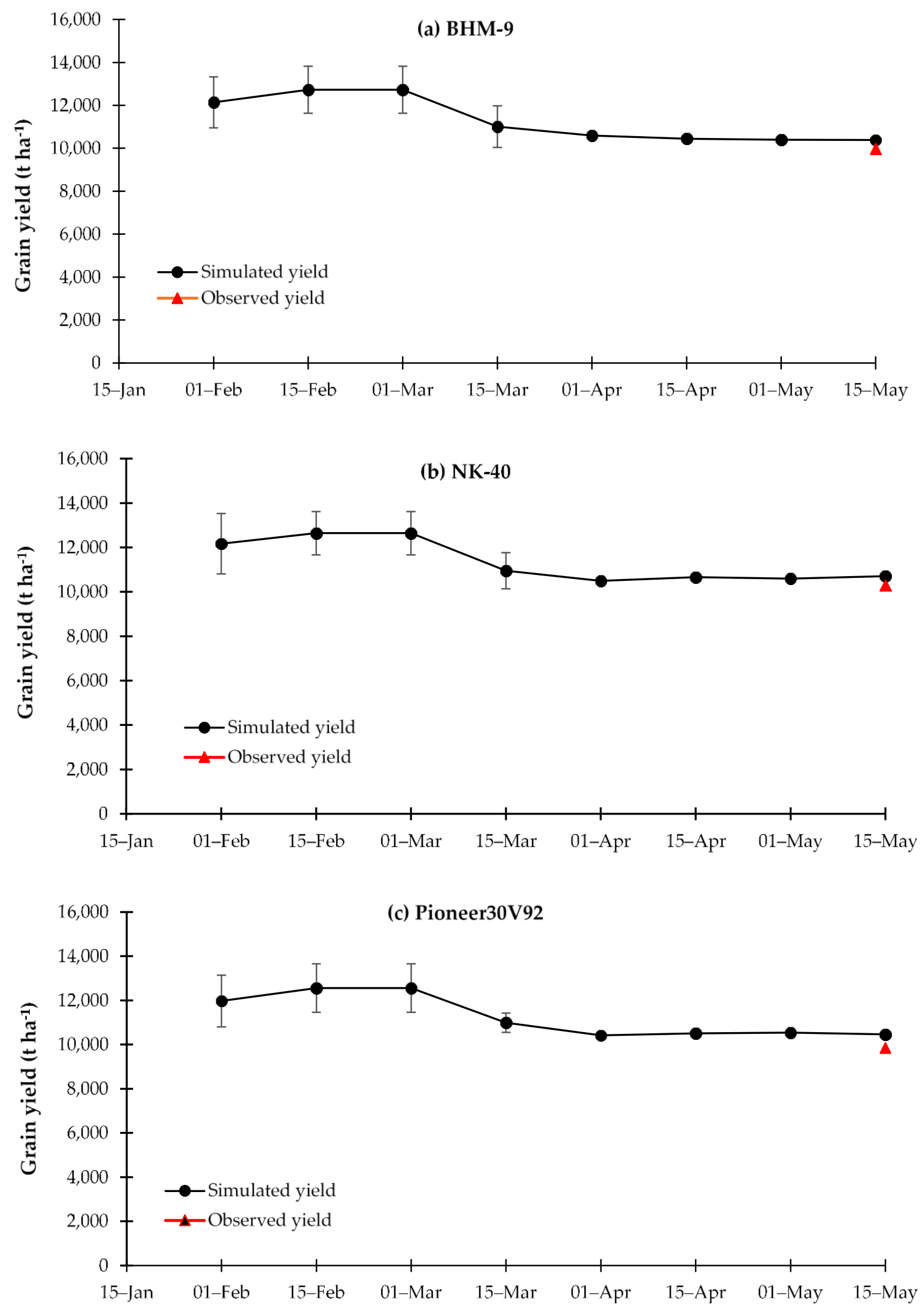

Figure 4. Average forecasted yield and standard deviation from the observed yield of the year 2017 considering the forecast date and yield $\left(\mathrm{kg} \mathrm{ha}^{-1}\right)$ for maize (a) BHM-9, (b) NK-40, and (c) Pioneer30V92. 


\section{Conclusions}

The CERES-Maize model was capable of simulating phenology and yield of three hybrid maize varieties for five sowing dates in the northern and western regions of Bangladesh. The simulated results were in close agreement with the observed values. The validated CERES-Maize model was able to estimate the attainable grain yield satisfactorily for various sowing dates. The seasonal analysis option of the model identified the optimum sowing windows for maize for both the northern and western region of Bangladesh. The optimum sowing window for Rangpur (northern region) was between 5 November to 5 December, and 5 to 20 November for Jashore (western region). Therefore, the study claimed that now maize can easily be fitted into rice-based cropping patterns at the northern and western regions of the country. Moreover, the model successfully forecasted the grain yield of the tested maize varieties at approximately 45 days prior to harvest. The study results will definitely be beneficial for the farmers to boost up the maize production under the adverse climatic conditions and also for the policy planners to estimate the future requirement for import maize to meet the national demand or for export if production is surplus. Further research would be needed for new varieties to determine the optimum sowing window(s) at different locations and to forecast the yield at the early stage of maize by using a multi-criteria model following an artificial neural network as well as using the DSSAT model.

Author Contributions: Conceptualization: A.K.C., M.S.H.M., T.Z., R.S., J.C.B., and S.A.; methodology: A.K.C., M.S.H.M., T.Z., R.S., J.C.B., and S.A.; investigation: A.K.C., M.S.H.M., T.Z., R.S., J.C.B., and S.A.; formal analysis: J.C.B., S.I., F.A., M.M., M.B.H., and P.C.S.; data curation: J.C.B., S.I., F.A., M.M., M.B.H., and A.H.; statistical expertise: J.C.B., S.I., F.A., M.M., M.B.H., and A.H.; writing—original draft: A.K.C., M.S.H.M., T.Z., R.S., J.C.B., S.A., J.C.B., S.I., F.A., M.M., and M.B.H.; writing —critical revision and editing: E.S.D., M.M.H., and A.H.; resources: A.K.C., M.M.H., and J.C.B.; supervision: A.K.C., M.S.H.M., J.C.B., and M.M.; funding: A.K.C., E.S.D., M.M.H. and A.H. All authors have read and agreed to the published version of the manuscript.

Funding: This study is funded by the Krishi Gobeshona Foundation (KGF) through Modeling Climate Change Impact on Agriculture and Developing Mitigation and Adaptation Strategies for Sustaining Agricultural Production in Bangladesh (CRP-II) Project and also funded by the Taif University Researchers Supporting Project number (TURSP-2020/85), Taif University, Taif, Saudi Arabia.

Institutional Review Board Statement: Not applicable.

Informed Consent Statement: Not applicable.

Data Availability Statement: The data that support the findings of this study are available from the corresponding author upon reasonable request.

Acknowledgments: The authors extend their appreciation to Krishi Gobeshona Foundation (KGF) through Modeling Climate Change Impact on Agriculture and Developing Mitigation and Adaptation Strategies for Sustaining Agricultural Production in Bangladesh (CRP-II) Project. The authors also extend their appreciation to Taif University for funding current work by Taif University Researchers Supporting Project number (TURSP-2020/85), Taif University, Taif, Saudi Arabia.

Conflicts of Interest: The authors declare no conflict of interest.

\section{References}

1. BBS (Bangladesh Bureau of Statistics). Yearbook of Agricultural Statistics of Bangladesh; Government of Bangladesh: Dhaka, Bangladesh, 2016; pp. 95-96.

2. Ali, M.Y.; Waddington, S.R.; Timsina, J.; Hodson, D.; Dixon, J. Maize-rice cropping systems in Bangladesh: Status and research needs. J. Agric. Sci. Technol. 2009, 3, 35-53.

3. Tollenaar, M.; Dwyer, L.M. Physiology of maize. In Crop Yield, Physiology and Processes; Smith, D.L., Hamel, C., Eds.; Springer: Berlin/Heidelberg, Germany, 1999; pp. 169-204.

4. Knoema, Bangladesh-Maize Production Quantity. Available online: https://knoema.com/atlas/Bangladesh/topics/ Agriculture/Crops-Production-Quantity-tonnes/Maize-production (accessed on 12 March 2021).

5. Muchow, R.C.; Sinclair, T.R.; Bennett, J.M. Temperature and Solar Radiation Effects on Potential Maize Yield across Locations. Agron. J. 1990, 82, 338-343. [CrossRef] 
6. Ahmed, J.; Elias, S.M. Socio-economic study of winter maize in some selected areas of Bangladesh. J. Rural Develop. 1988, $18,60-68$.

7. Dahmardeh, M. Effects of sowing date on the growth and yield of maize cultivars (Zea mays L.) and the growth temperature requirements. Afr. J. Biotechnol. 2012, 11, 12450-12453. [CrossRef]

8. Sur, H.S.; Sharma, A.R. Response to sowing dates and performance of different sunflower hybrids during rainy season in high-intensity cropping systems. Indian J. Agric. 1999, 69, 683-689.

9. Soler, C.M.T.; Hoogenboom, G.; Sentelhas, P.C.; Duarte, A.P. Impact of Water Stress on Maize Grown Off-Season in a Subtropical Environment. J. Agron. Crop. Sci. 2007, 193, 247-261. [CrossRef]

10. Zhao, Y.; Potgieter, A.B.; Zhang, M.; Wu, B.; Hammer, G.L. Predicting Wheat Yield at the Field Scale by Combining HighResolution Sentinel-2 Satellite Imagery and Crop Modelling. Remote. Sens. 2020, 12, 1024. [CrossRef]

11. Holzworth, D.P.; Huth, N.I.; Devoil, P.G.; Zurcher, E.J.; Herrmann, N.I.; McLean, G.; Chenu, K.; Van Oosterom, E.J.; Snow, V.; Murphy, C.; et al. APSIM-Evolution towards a new generation of agricultural systems simulation. Environ. Model. Softw. 2014, 62, 327-350. [CrossRef]

12. Jones, J.W.; Hoogenboom, G.; Porter, C.H.; Boote, K.J.; Batchelor, W.D.; Hunt, L.A.; Wilkens, P.W.; Singh, U.; Gijsman, A.J.; Ritchie, J.T. The DSSAT cropping system model. Eur. J. Agron. 2003, 18, 235-265. [CrossRef]

13. Rezzoug, W.; Gabrielle, B.; Suleiman, A.; Benabdeli, K. Application and evaluation of the DSSAT-wheat in the Tiaret region of Algeria. Afr. J. Agric. Res. 2008, 3, 284-296.

14. Tovihoudji, P.G.; Akponikpè, P.B.I.; Agbossou, E.K.; Bielders, C.L. Using the DSSAT Model to Support Decision Making Regarding Fertilizer Microdosing for Maize Production in the Sub-humid Region of Benin. Front. Environ. Sci. 2019, 7, 1-15. [CrossRef]

15. Hoogenboom, G.; Jones, J.W.; Wilkens, R.W.; Porter, C.H.; Boote, K.J.; Hunt, L.A. Decision Support System for Agro-Technology Transfer (DSSAT), version 4.6; DSSAT Foundation: Prosser, WA, USA, 2005.

16. Adnan, A.A.; Jibrin, J.M.; Kamara, A.Y.; Abdulrahman, B.L.; Shaibu, A.S.; Garba, I.I. CERES-Maize Model for Determining the Optimum Planting Dates of Early Maturing Maize Varieties in Northern Nigeria. Front. Plant Sci. 2017, 8, 1118. [CrossRef]

17. Adnan, A.A.; Jibrin, J.M.; Kamara, A.Y.; Abdulrahman, B.L.; Shaibu, A.S. Using CERES-Maize model to determine the nitrogen fertilization requirements of early maturing maize in the Sudan Savanna of Nigeria. J. Plant Nutr. 2017, 40, 1066-1082. [CrossRef]

18. Corbeels, M.; Chirat, G.; Messad, S.; Thierfelder, C. Performance and sensitivity of the DSSAT crop growth model in simulating maize yield under conservation agriculture. Eur. J. Agron. 2016, 76, 41-53. [CrossRef]

19. MacCarthy, D.S.; Adiku, S.G.K.; Freduah, B.S.; Gbefo, F.; Kamara, A.Y. Using CERES-Maize and ENSO as Decision Support Tools to Evaluate Climate-Sensitive Farm Management Practices for Maize Production in the Northern Regions of Ghana. Front. Plant Sci. 2017, 8, 31. [CrossRef] [PubMed]

20. Lizaso, J.I.; Boote, K.J.; Jones, J.W.; Porter, C.H.; Echarte, L.; Westgate, M.E.; Sonohat, G. CSM-IXIM: A New Maize Simulation Model for DSSAT Version 4. Agron. J. 2011, 103, 766-779. [CrossRef]

21. Kumar, R.; Singh, K.K.; Gupta, B.R.D.; Baxla, A.K.; Rathore, L.S.; Attri, S.D. Optimum sowing dates for soybean in central India using CROPGRO and ClimProb symbiosis. Meteorol. Appl. 2002, 9, 247-254. [CrossRef]

22. Bannayan, M.; Crout, N.M.J.; Hoogenboom, G. Application of the CERES-Wheat Model for Within-Season Prediction of Winter Wheat Yield in the United Kingdom. Agron. J. 2003, 95, 114-125. [CrossRef]

23. Wang, X.; Huang, J.; Feng, Q.; Yin, D. Winter Wheat Yield Prediction at County Level and Uncertainty Analysis in Main Wheat-Producing Regions of China with Deep Learning Approaches. Remote. Sens. 2020, 12, 1744. [CrossRef]

24. Niedbała, G.; Nowakowski, K.; Rudowicz-Nawrocka, J.; Piekutowska, M.; Weres, J.; Tomczak, R.J.; Tyksiński, T.; Pinto, A. Álvarez Multicriteria Prediction and Simulation of Winter Wheat Yield Using Extended Qualitative and Quantitative Data Based on Artificial Neural Networks. Appl. Sci. 2019, 9, 2773. [CrossRef]

25. Jahan, M.; Sen, R.; Ishtiaque, S.; Choudhury, A.K.; Akhter, S.; Ahmed, F.; Biswas, J.C.; Manirruzaman, M.; Miah, M.M.; Rahman, M.; et al. Optimizing sowing window for wheat cultivation in Bangladesh using CERES-wheat crop simulation model. Agric. Ecosyst. Environ. 2018, 258, 23-29. [CrossRef]

26. Soler, C.M.T.; Sentelhas, P.C.; Hoogenboom, G. Application of the CSM-CERES-Maize model for planting date evaluation and yield forecasting for maize grown off-season in a subtropical environment. Eur. J. Agron. 2007, 27, 165-177. [CrossRef]

27. Chisanga, C.B.; Phiri, E.; Shepande, C.; Sichingabula, H. Evaluating CERES-Maize Model Using Planting Dates and Nitrogen Fertilizer in Zambia. J. Agric. Sci. 2015, 7, 1-19. [CrossRef]

28. Jones, J.W.; He, J.; Boote, K.J.; Wilkens, P.; Porter, C.; Hu, Z.; Ahuja, L.R.; Ma, L. Estimating DSSAT Cropping System CultivarSpecific Parameters Using Bayesian Techniques. In Methods of Introducing System Models into Agricultural Research; John Wiley \& Sons: Madison, WI, USA, 2011.

29. Hunt, L.A.; Boote, K.J. Data for model operation, calibration and evaluation. In Understanding Options for Agricultural Production; Tsuji, G.Y., Hoogenboom, G., Thornton, P.K., Eds.; Kluwer Academic Publishers: Dordrecht, The Netherlands, 1998 ; pp. 9-39.

30. Willmott, C. Some comments on the evaluation of model performance. Bull. Am. Meteorol. Soc. 1982, 63, 1309-1313. [CrossRef]

31. Ahmed, I.; Rahman, M.H.U.; Ahmed, S.; Hussain, J.; Ullah, A.; Judge, J. Assessing the impact of climate variability on maize using simulation modeling under semi-arid environment of Punjab, Pakistan. Environ. Sci. Pollut. Res. 2018, 25, 28413-28430. [CrossRef]

32. Kiniry, J.; Williams, R.; Vanderlip, J.; Atwood, D.; Muuliken, W.; Cox, H.; Weibold, W. Evaluation of two maize models for nine U.S. locations. Agron. J. 1997, 89, 421-426. [CrossRef] 
33. Jones, J.; Hoogenboom, G.; Wilkens, P.; Porter, C.; Tsuji, G. Decision Support System for Agrotechnology Transfer Version 4.Volume DSSAT v4.5: ICASA Tools; University of Hawaii: Honolulu, HI, USA, 2010.

34. Liu, X.; Andresen, J.; Yang, H.; Niyogi, D. Calibration and Validation of the Hybrid-Maize Crop Model for Regional Analysis and Application over the U.S. Corn Belt. Earth Interact. 2015, 19, 1-16. [CrossRef]

35. Mubeen, M.; Ahmad, A.; Wajid, A.; Khaliq, T.; Hammad, H.M.; Sultana, S.R.; Ahmad, S.; Fahad, S.; Nasim, W. Application of CSM-CERESMaize model in optimizing irrigated conditions. Outlook Agric. 2016, 45, 173-184. [CrossRef]

36. Lin, Y.; Wu, W.; Ge, Q. CERES-Maize model-based simulation of climate change impacts on maize yields and potential adaptive measures in Heilongjiang Province, China. J. Sci. Food Agric. 2014, 95, 2838-2849. [CrossRef]

37. Liaqat, W.; Ahmad, H.; Jan, M.F.; Ali, N.; Anjum, M.M.; Rehan, W. Effect of sowing dates on yield of different maize hybrids during summer in Nowshera, Pakistan. Middle East J. Agric. Res. 2018, 7, 554-558.

38. Biswas, M. Direct Seeded and Transplanted Maize: Effects of Planting Date and Age of Seedling on the Yield and Yield Attributes. Am. J. Exp. Agric. 2015, 5, 489-497. [CrossRef]

39. Porter, J.R.; Semenov, M.A. Crop responses to climatic variability. Phil. Trans. R. Soc. B 2005, 360, 2021-2035. [CrossRef] [PubMed]

40. Thornton, P.; Bowen, W.; Ravelo, A.; Wilkens, P.; Farmer, G.; Brock, J.; Brink, J. Estimating millet production for famine early warning: An application of crop simulation modelling using satellite and ground-based data in Burkina Faso. Agric. For. Meteorol. 1997, 83, 95-112. [CrossRef]

41. Garcia y Garcia, A.; Hoogenboom, G.; Soler, C.M.T.; Stooksburry, D.E. The impact of climate variability on peanut yield forecasts in Georgia. In Annual Meetings Abstracts [CD-ROM]; ASA, CSSA, and SSSA: Madison, WI, USA, 2003.

42. Boggione, I.M.; Andrade, C.D.L.T.D.; Júnior, J.C.F.B.; Viana, J.H.M. Modeling Appliedto Sowing Dateof Irrigated Maize. Rev. Bras. MilhoSorgo 2018, 17, 201-215. [CrossRef]

43. Amaral, T.A.; Andrade, C.D.L.T.D.; Alves, M.E.B.; Silva, D.F. Applying CSM-CERES-Maize to define a sowing window for irrigated maize crop-The Riacho's Farm case study. Ambient. Agua Interdiscip. J. Appl. Sci. 2011, 6, 38-53. [CrossRef] 